\title{
The skin landscape in diabetes mellitus. Focus on dermocosmetic management
}

This article was published in the following Dove Press journal:

Clinical, Cosmetic and Investigational Dermatology

14 May 2013

Number of times this article has been viewed

\section{Gérald E Piérard' \\ Sophie Seité ${ }^{2}$ \\ Trinh Hermanns-Lê ${ }^{3}$ \\ Philippe Delvenne ${ }^{3}$ \\ André Scheen ${ }^{4}$ \\ Claudine Piérard- \\ Franchimont ${ }^{3}$}

'Laboratory of Skin Bioengineering and Imaging (LABIC), University of Liège, Liège, Belgium; ${ }^{2}$ La RochePosay Pharmaceutical Laboratories, Asnières, France; ${ }^{3}$ Department of Dermatopathology, Unilab Lg, Liège University Hospital, Liège, Belgium; ${ }^{4}$ Department of Diabetology, Nutrition and Metabolic Diseases, and Clinical Pharmacology Unit, Liège University Hospital, Liège, Belgium
Correspondence: Gérald E Piérard Laboratory of Skin Bioengineering and Imaging ( $L A B I C)$, University of Liège, $\mathrm{B}-4000$ Liège, Belgium

Tel +32 43662408

Fax +32 43662976

Email gerald.pierard@ulg.ac.be
Background: Some relationships are established between diabetes mellitus (DM) and a series of cutaneous disorders. Specific dermatoses are markers for undiagnosed DM. Other disorders represent supervening complications in an already treated DM patient.

Objective: To review the information about dermocosmetic care products and their appropriate use in the management and prevention of dermatoses related to DM.

Method: The peer-reviewed literature and empiric findings are covered. Owing to the limited clinical evidence available for the use of dermocosmetics, a review of the routine practices and common therapies in DM-related dermatoses was conducted.

Results: Some DM-related dermatoses (acanthosis nigricans, pigmented purpuric dermatosis) are markers of macrovascular complications. The same disorders and some others (xerosis, Dupuytren's disease) have been found to be more frequently associated with microangiopathy. Other skin diseases (alopecia areata, vitiligo) were found to be markers of autoimmunity, particularly in type $1 \mathrm{DM}$. Unsurprisingly, using dermocosmetics and appropriate skin care has shown objective improvements of some DM-related dermatoses, such effects improve the quality of life. The most common skin manifestations of DM fall along continuum between "dry skin," xerosis, and acquired ichthyosis, occurring predominately on the shins and feet. Dermocosmetic products improve the feeling of well-being for DM patients.

Keywords: diabetes mellitus, skin, dermocosmetics, diabetic xerosis

\section{Introduction}

Diabetes mellitus (DM) is a metabolic disorder corresponding to a relative-to-complete insulin deficiency. This condition leads to gross alterations in glucose, fat, and protein metabolism. In type $1 \mathrm{DM}$, insulin insufficiency results from a gradual, immunemediated destruction of the pancreatic $\beta$ islet cells. By contrast, in type $2 \mathrm{DM}$, chronic hyperglycemia mainly results from end-organ (particularly the liver and skeletal muscles) insulin resistance. This condition is accompanied by a progressive, agerelated decrease in pancreatic insulin release. A genetic predisposition and a strong association with obesity exist in type $2 \mathrm{DM}$.

$\mathrm{DM}$ is a major cause of morbidity and mortality. Any skin structure may be altered by DM. The prevalence of DM-associated skin morbidity is far from being trivial. ${ }^{1-7}$ Some disorders represent an early indicator of a yet undiagnosed DM. Other skin changes occur even when adequate DM treatment has already been initiated. Two types of noninfectious dermatoses with distinct pathobiologic background have been distinguished. These include some lesions, which are markers of poor glycemic control, and a cluster of skin changes representing DM-related manifestations of autoimmunity. ${ }^{8}$ 
The prevalence of DM-associated skin infections is commonly increased compared with the normal population. ${ }^{7}$

One of the main direct biologic effects of hyperglycemia is nonenzymatic glycation, which alters various structural and regulatory proteins. This process occurs naturally during aging and is severely boosted in DM, leading to the build up of advanced glycation end (AGE) products. The amount of skin AGE products strongly correlates with DM-related microvasculopathy, including retinopathy and nephropathy. ${ }^{9-14}$ Several immunomodulatory mechanisms are altered in DM and thus reduce the defense mechanisms to infections.

Of note, most of the DM-associated dermatoses are not specific for this endocrinopathy. Other pathogenic factors are possibly involved. Many of them have not been clearly identified so far.

During the last years, efforts have been streamed within the dermocosmetics and pharmaceutics industries towards the development of various topical treatments targeting some of the skin complications of DM. These have been mainly driven by the knowledge that at certain points of the disease, the existing therapies were no longer able to slow down the progression of the skin changes. Evidence-based support for the use of dermocosmetics as adjunctive therapy remains modest. Therefore, practice is based on anecdotal reports or studies with limited control.

This work provides an updated review of (a) the physiopathologic changes altering the skin of DM patients, and (b) the dermocosmetic formulations adapted to these conditions. Evidence-based support for the use of dermocosmetic formulations and make-up as adjunctive DM management remains scarce. Practice is based on personal experience, anecdotal reports, and studies with limited control.

\section{Direct skin complications of DM}

The complications of DM directly affecting the skin involve the microvasculature, the extravascular dermal matrix, the dermoepidermal junction, the epidermis, hair follicles, sweat glands, and the hypodermis as well (Tables 1 and 2). Pruritus and sensorial irritation (sensitive skin) are frequently reported. ${ }^{6}$ Whenever possible, proactive management, using

Table I Skin disorders associated with DM

\begin{tabular}{ll}
\hline Type I DM & Type 2 DM \\
\hline Alopecia areata & Acanthosis nigricans \\
Necrobiosis lipoidica & Facial erythrosis \\
Vitiligo & Pigmented purpuric dermatosis \\
& Xerosis \\
\hline
\end{tabular}

Abbreviation: DM, diabetes mellitus. dermocosmetic formulations, may prove to be critical for the perception of well-being in DM patients. Early education and continued encouragement most probably benefit patient quality of life. Skin cleansing removes dirt and other xenobiotics along with sebum. This can be harsh and may be particularly detrimental to skin when the skin barrier is already disturbed. Without professional guidance, patients may experiment with inappropriate self-care behaviors. In general, due to the lack of evidence supporting their use, patients should avoid washing with aggressive soaps.

\section{Angiopathy}

Macro- and microangiopathy largely contribute to the cutaneous complications of DM. DM patients have increased vascular leakiness, with increased vessel wall permeability. The vascular responsiveness to sympathetic innervation is lowered, as well as the response to thermal and hypoxemic stress.

Microangiopathy is a major complication of DM, as it is responsible for retinopathy, nephropathy, and peripheral neuropathy. The microvascular network of the skin is particularly altered in DM, and this worsens with age. ${ }^{15}$ The perivascular basement membranes are thickened, and the endothelial cells pile up. ${ }^{16,17}$ Type IV collagen and laminin are deposited in excess. The vascular lumen shows uneven dilation and narrowing. These latter changes are clinically obvious during periungual capillaroscopy. Similar aspects are found in facial rubeosis, diabetic dermopathy and necrobiosis lipoidica.

On the lower limbs, macroangiopathy of the large blood vessels is due to the combination of atherosclerosis and vasculitis. This condition is seen frequently in DM patients, in whom this is superimposed over microangiopathy. These combined processes lead to a chronic reduction in oxygen supply and is responsible for skin atrophy, foot hypothermia, vellus hair rarefaction, and onychodystrophies. In addition, distal neuropathy, as well as traumatisms and infectious agents, participates in the development of both DM ulcers and DM foot syndrome; once ulcer develops, peripheral vascular disease and the intrinsic disturbance in wound healing contribute to adverse outcomes. ${ }^{18}$

No direct effect on micro- and macroangiopathy is expected from the use of dermocosmetic products. ${ }^{6}$ However, some formulations help to correct the consequences of the vascular damage. This is particularly the case for the products targeting dry/harsh skin by boosting epidermal renewal. ${ }^{6}$

\section{Erythrosis}

An erythrosis reaction is commonly present on the face of DM patients. ${ }^{8}$ Other parts of the body are possibly affected by 
Table 2 Correlations reported between some dermatoses and DM complications

\begin{tabular}{|c|c|c|c|c|}
\hline Dermatosis & Macroangiopathy & Nephropathy & Retinopathy & Neuropathy \\
\hline Acanthosis nigricans ${ }^{81}$ & + & + & & \\
\hline Dermopathy ${ }^{26}$ & & + & + & + \\
\hline Dupuytren's disease ${ }^{32}$ & & & + & \\
\hline Pigmented purpuric dermatosis ${ }^{17}$ & + & & & + \\
\hline Sclerodermoid syndrome ${ }^{29}$ & & & + & + \\
\hline
\end{tabular}

Abbreviation: DM, diabetes mellitus.

the same process as well. Daily photoprotection is important when the skin has become more sensitive to UV radiation and where treatments have lead to pigmentary changes. Recommendations point to the use of a broad-spectrum sunscreen with SPF and UVA-PF, depending on the patient's phototype and photosensitivity. ${ }^{19,20}$ In addition, the use of appropriate nonirritant hygiene products are empirically recommended, in order to avoid a worsening of the clinical signs.

\section{AGE products}

The AGE products are implicated in the functional microangiopathy, secondary to the increased blood cell viscosity and the consecutive reduction in blood flow. The peripheral neuropathy adds its functional effects to the glycation process, and the combination increases their clinical signs. ${ }^{21}$ In addition, glycation alters some physicochemical characteristics of the fibrous collagen, and glycation is further responsible for a yellowish hue of the skin and nails.

Skin glycation creates new molecular residues and induces cross-links in the extracellular matrix of the dermis. The formation of such cross-links between macromolecules contributes to altered elasticity and the modification of other physical characteristics of the dermis in DM patients, similar to those observed during intrinsic aging and photoaging. ${ }^{22}$ Some glycation inhibitors have been described. ${ }^{23,24}$ Aminoguanidine is probably the most widely used glycation inhibitor. Other compounds, including resveratrol, carnosine, and blueberry extract, exhibit some in vitro antiglycation activity. Nevertheless, studies evaluating the impact of topical products containing AGE inhibitor on the improvement of DM skin are currently missing. A 12 -week study of 20 DM patients using a topical product enriched with an AGE inhibitor and a glycosaminoglycan (GAG) synthesis stimulator failed to show any change in skin AGE products, as evaluated by a skin autofluorescence measurement. ${ }^{25}$

Protein glycation is accompanied by the generation of reactive oxygen species (ROS) through the autoxidation of glucose and glycated proteins and via the interaction of AGE products with cell surface receptors for AGE
(RAGE). ${ }^{11,14}$ Hence, the application of a topical product containing antioxidants or a combination of antiglycation and antioxidant has been postulated to be a safe and simple care targeting some DM skin complications. ${ }^{25}$

AGE products are clearly involved in some skin disorders related to DM. However, the cross-links between macromolecules and the extracellular matrix, and the generation of ROS, are insufficient to explain the pathogenesis of all the DM-associated skin diseases.

\section{Diabetic dermopathy}

Diabetic dermopathy is a common nonspecific condition affecting as many as $30 \%-60 \%$ of DM patients. Lesions begin as multiple discretely erythematous, coin-shaped macules or annular rings and are prevalent on the shins. The skin spots commonly regress after a few years, leaving atrophic hyperpigmented areas. The vessel walls are thickened, and Factor XIIIa+ dermal dendrocytes are abundant. The occurrence of lesions correlate with retinopathy, nephropathy, and neuropathy. ${ }^{26}$ No treatment is necessary for individual atrophic macules; these are asymptomatic and are not directly associated with increased local morbidity.

\section{Pigmented purpuric dermatosis}

Pigmented purpuric dermatosis, also known under its eponym Schamberg disease, is prevalent in DM patients. It is characterized by a discrete, lymphoid capillaritis, showing leakage of erythrocytes. A drug reaction is identified in some patients. This condition is closely related to alterations of the perivascular basement membranes. ${ }^{17}$

We suggest that the presence of yellow skin on the hands, rubeosis faciei, and pigmented purpuric dermatosis can prompt the use of make-up with a high pigment concentration, to cover the skin lesions. It is important to avoid any occlusive effect at risk of worsening the clinical manifestations.

\section{Necrobiosis lipoidica}

Necrobiosis lipoidica is a rare disorder affecting about $0.3 \%$ of DM patients. This skin condition predominantly affects women, from 30-40 years and older. It is considered 
as a skin marker of possible DM. However, the severity of hyperglycemia and poor diabetic control do not correlate with the occurrence of necrobiosis lipoidica. Skin lesions appear as infiltrated yellow-brown plaques, often located on the shins. The macules merge to form sharply circumscribed scleroatrophic plaques with scalloped outlines. The clinical course is often indolent, with spontaneous remission in less than $20 \%$ of cases. By contrast, painful ulcerations can develop, and wound healing is particularly difficult. A lymphoid cell infiltrate is distributed throughout the dermis with focal collections, in a granulomatous pattern. A prominent microangiopathy is present, and the perivascular stroma is remodeled with abundant deposits of acidic proteoglycans, collagen bundles, and lipids. Dermal dendrocytes are quite numerous in the early lesions. They are likely involved in the active process of dermal remodelling. ${ }^{27}$

At present, the treatment of necrobiosis lipoidica is disappointing. A focus should be placed on the prevention of ulcers.

\section{Granuloma annulare}

Granuloma annulare histopathologically resembles focal areas of necrobiosis lipoidica somewhat. In rare instances, it is associated with DM, particularly when the pattern of distribution is widespread. The association of necrobiosis lipoidica with granuloma annulare and sarcoidosis has been reported. $^{28}$

\section{Thick and waxy diabetic skin}

Several specific scleroderma-like syndromes are associated with a localized thickening of the skin, in DM. ${ }^{29}$ The common underlying pathogenesis involves molecular alterations in collagen and GAGs. The clinical syndromes are the result of increased deposition and improper degradation of these macromolecules, and they are likely related to the formation of AGE products.

About $30 \%$ of patients with type 1 and type 2 DM exhibit a waxy infiltration of the skin of the extremities, generally associated with painless, limited joint mobility. This presentation is a marker of microangiopathy risk, but it remains unclear whether the pathogenic origins of the skin and joints are similar. The viscoelastic properties of the skin are usually more altered in type $1 \mathrm{DM}$ than in type $2 \mathrm{DM}$. Monitoring these changes could help predicting the evolution of DM. ${ }^{30,31}$ Acral pseudoscleroderma is a risk indicator for nephropathy in type $1 \mathrm{DM}$. It is also predictive for retinopathy and neuropathy in both DM types.
Most important, intensive insulin therapy is central in the prevention and, possibly, the treatment of limited joint mobility and scleroderma-like syndrome. Long-term tight glycemic control leads to decreased AGE products in the skin, and delayed onset and severity of limited joint mobility. ${ }^{32}$

\section{Scleredema diabeticorum}

Scleredema affects about $30 \%$ of type 2 DM patients, particularly obese men. ${ }^{33}$ The skin is typically infiltrated and indurated on the upper back, neck, shoulders, and occasionally the chest. The dermis is thickened, and the collagen bundles are coarse and embedded in an excess of acidic GAGs. The glycation process is probably involved in the pathogenesis of scleredema. Most patients with DM-scleredema become insulin dependent. Scleredema is difficult to treat, ${ }^{34-36}$ and these patients have multiple complications of DM. ${ }^{37}$

\section{Perforating disorders}

In severe DM patients prone to renal failure, perforating collagenosis is occasionally present on the extensor aspects of the extremities. Hyperkeratotic papules contain collagen fibres in their way of transepidermal extrusion. These lesions are pruriginous, and an isomorphic phenomenon is commonly present. Treatment for the perforating disorders is usually unsuccessful. ${ }^{36}$ Again, the focus should be placed on prevention, by avoiding excessive friction and pressure forces.

\section{Diabetic bullosis}

Abrupt spontaneous blisters occasionally develop on the lower extremities of type 1 DM patients suffering from peripheral neuropathy. The epidermis is lifted off at the level of the dermoepidermal basement membrane. Immunoreactants (immunoglobulins, complement) are typically absent in the skin lesions. The pathogenesis remains uncertain, although the neuropathy seems to play a prominent role. ${ }^{38}$

Diabetic bullosis is, in part, prevented by frequent topical applications of dermocosmetic formulations, increasing the epidermal biologic activity and reducing the mechanical impact of xerosis.

\section{Diabetic xerosis and callus}

Xerosis is a common feature in DM patients. ${ }^{7,39}$ It results from an abnormal, persistent cohesion between corneocytes, with secondary thickening of the tidy stratum corneum (SC), impaired moisturization of the uppermost SC layers, 
increased transit time of corneocytes in the SC, and altered skin barrier function. ${ }^{39-43}$ Diabetic xerosis appears to be correlated with microangiopathy.

Clinical evaluations of xerosis ${ }^{44}$ are conveniently magnified, using dedicated noninvasive biometrological methods. ${ }^{45-47}$ These have shown the effects of aging and those of the environment to be superimposed over the consequences of DM. ${ }^{48-50}$ The physical characteristic of the SC depends on its water-content and -holding capacity. ${ }^{51,52}$ Electrometric measurements represent a convenient method for monitoring SC moisture. ${ }^{53-58}$ Harvesting the superficial corneocytes can also provide information about the severity of xerosis. ${ }^{59-65}$ Finally, the rate of exfoliation is conveniently assessed using the dansyl chloride test ${ }^{66-68}$ or the dihydroxyacetone test. ${ }^{69,70}$

Callus formation results from excessive pressure. It precedes necrosis and the breakdown of the soft tissue over the bony prominences of the feet, usually on the big toe and sole, and over the first and/or second metacarpophalangeal joints. ${ }^{71}$ Foot DM ulcers are surrounded by a ring of callus. Xerosis and callus prevention are important interventions that physicians and other health care professionals should provide to decrease the risk of DM ulcer.

Moisturizers and emollients bind water to the SC, improving the skin surface hydration. This has been repeatedly shown to improve the epidermal barrier function and to reduce the stinging, scaling, redness, and cracks associated with xerosis. ${ }^{72-78}$ Adequate hydration improves the barrier function, reduces pruritus, and prevents infections related to scratching. ${ }^{74}$

Although emollients represent a regular adjunct to other topical treatments for patients affected by some dermatoses, studies evaluating their impact on skin improvement in DM are few in number. Xerosis and reduced SC elasticity possibly lead to SC cracks, followed by bacterial invasion and infection. Recently, it was shown that an increased severity in xerosis was linked to the duration of DM. This condition was associated with desquamation and pruritus. Emollients frequently counteract all these alterations. ${ }^{79}$

Urea-based formulations enhance the penetration of other topical agents applied to thickened, keratotic, scaly skin. ${ }^{79}$ The prevention and removal of callus, especially in high-risk patients, plays a crucial role in ulcer prevention by significantly reducing focal plantar pressures. High concentration urea-based moisturizers may be particularly suitable for the removal and prevention of hyperkeratosis and callus (Figure 1). In addition, the proper applications of topical agents by the patient reduces costs associated with podiatric treatments and possibly improves compliance to skin care. ${ }^{79}$
A

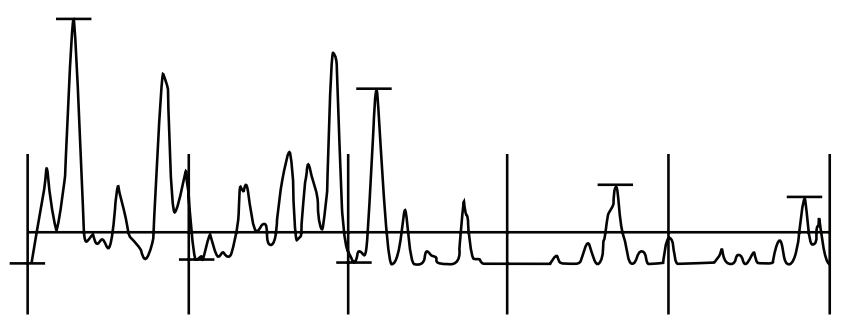

Figure I Profilometry of the skin surface in a diabetic patient. The sample comprises an untreated xerotic part (A) and a contiguous field (B) treated for 5 days with a urea-based cosmetic formulation.

Note: The amplitude of the skin surface relief is reduced by half on the treated area.

\section{Acanthosis nigricans}

Some patients with type $2 \mathrm{DM}$ are prone to develop acanthosis nigricans. The lesions present clinically as a brown to gray-black, velvety, and papillomatous thickening of the skin. The lesions typically involve large folds, particularly the axillae, the posterolateral neck, groins, and abdominal folds. Any other part of the body can also be involved, including the palms (tripe palms) and soles. Associated skin tags are common.

Acanthosis nigricans is a marker for a group of endocrine disorders characterized by insulin resistance, which can be present in type $2 \mathrm{DM}^{80,81}$ The action of insulin on the insulin-like growth factor-1 (IGF-1)-receptor appears to mediate abnormal epidermal proliferation and the resulting presentation of acanthosis nigricans. Any occurrence of DMrelated acanthosis nigricans represents a prognostic indicator for micro- and macrovascular complications. The treatment of acanthosis nigricans is generally ineffective. Topical treatment with calcipotriol, salicylic acid, urea, systemic and topical retinoids have all been used with anecdotal success. ${ }^{82}$

\section{Onychodystrophy}

Onychodystrophies are frequent in DM patients, although none are specific for DM. ${ }^{83}$ They include Beau's lines, onycholysis, yellowish discoloration, and splinter blood suffusions. The lesions are possibly more severe in winter, reflecting functional changes associated with the micro- and macroangiopathy. ${ }^{83}$

Compared to non-DM subjects with nail alterations, DM patients show a higher proportion of onychomycosis relative to noninfectious onychodystrophies ${ }^{84} \mathrm{DM}$ men suffer more frequently from onychomycosis and onychodystrophy than DM women. DM patients with compromised lower extremities and severe neuropathy are at increased risk for developing complications from onychomycosis. Thus, there is an 
important clinical rationale for early identification and for adequately treating DM patients with nail alterations.

\section{Reduced hair fullness}

Hair is thinned, fragile and sparse on the scalp of DM patients. ${ }^{85}$ Corporal vellus hairs are possibly affected as well.

\section{Altered sweating}

Sweating is reduced on the lower extremities of DM patients. This condition results from the peripheral neuropathy. There is some compensatory hyperhidrosis on the upper part of the body. ${ }^{86-95}$ In areas with excessive sweating, a gentle antiperspirant or deodorant dedicated to these patients may be of interest. ${ }^{94}$

\section{Pruritus}

Pruritus is frequently present in DM patients. ${ }^{96}$ Occasionally, this predominates on the genital areas.

\section{Membranous lipodystrophy}

Membranous lipodystrophy refers to pseudocystic cavities located in the hypodermis following the focal necrosis of lobules of adipose cells. A hyaline shell is commonly present at the periphery of the lesions.

There is no preventive and treating procedure recognized for membranous lipodystrophy.

\section{Indirect skin modifications Infectious complications}

It is not clearly established that patients with poor glycemic control are more susceptible to common bacterial skin infections than the normal population. However, the response to infection is commonly weakened. It is important that DM patients maintain an intact mucocutaneous barrier. Dermatophytoses are not more prevalent in DM but open the way to other common pathogens. In such instance, erysipela frequently ensues.

Mucocutaneous infections with Candida spp. are an early indicator of an undiagnosed DM or an inadequately controlled glycemia. They exhibit various clinical presentations. The adhesion of Candida yeasts to the SC is possibly increased in DM patients compared with the normal population. ${ }^{97}$

It is important to pay attention to rare but severe skin infections, including the malignant external otitis due to Pseudomonas aeruginosa and the necrotizing soft tissue infections. Hyperglycemia favors some other opportunistic diseases, such as the devastating infections caused by Mucorales zygomycetes. Facial rhinocerebral mucormycosis is a typical example.

\section{Secondary metabolic changes}

Xanthochromia responsible for a yellowish hue is in part linked to the xerotic process. Carotenemia is occasionally present in DM patients and confers an orange hue to the skin.

Eruptive xanthomas can onset rapidly as a result of major hypertriglyceridemia, in poorly controlled DM. They occur as crops of yellowish tiny papules surrounded by an erythematous halo, grouped on the extensor aspects the limbs. The lesions are due to a lipidic load in the perivascular dendrocytes. ${ }^{98}$

\section{Associated diseases}

The increased prevalence of type $1 \mathrm{DM}$ is associated with a series of immune-mediated disorders, including vitiligo, alopecia areata, dermatitis herpetiformis, autoimmune thyroiditis, and Biermer's anemia. ${ }^{99}$ Generalized eruptive clear cell syringomas are particularly associated with DM.

Migratory necrolytic erythema is a rare disorder in the glucagonoma syndrome spectrum. This latter neoplasm is issued from the alpha cells in the Langerhans islets of the pancreas.

\section{Complications of DM treatments}

Drug reactions rarely occur following oral DM therapy. However, a maculopapular rash may develop during the first months of treatment. Urticaria, lichenoid eruptions, Stevens-Johnson syndrome, and toxic epidermal necrolysis have all been reported. ${ }^{100}$ Adverse reactions to insulin are rare. ${ }^{101}$ Nevertheless, lipohypertrophic lesions, mainly in the abdominal wall, are still quite commonly observed in patients chronically treated with a continuous subcutaneous insulin infusion, even with ultrashort insulin analogs. ${ }^{102}$

\section{Conclusion}

Metabolic changes associated with DM exert a major impact on the skin. The microvascular network is particularly altered. The nonenzymatic glycation of diverse macromolecules is a major biologic factor, as is the peripheral neuropathy. Cutaneous disorders associated with DM commonly bother and cause pain to DM patients, and impact their quality of life, including interpersonal relationships. Cosmetics and appropriate skin care management contribute to a feeling of well-being and comfort. ${ }^{79}$ Unsurprisingly, they have been 
shown to objectively improve the quality of life of DM patients. ${ }^{50}$ Clearly, skin care with moisturizers, low-irritant cleansers, and make-up may be effective in improving skin physiology and controlling or covering up some dermatoses associated with DM.

Some recommendations are expressed:

- There is evidence suggesting that daily applications of a moisturizing formulation on the body, particularly on compromised lower extremities, often control both pruritus and xerosis. Emollients containing urea, with or without antiglycation agents and antioxidants, may be indicated.

- The prevention and removal of callus remain essential.

- Products containing phthalate should be discarded, although further studies are needed to determine whether phthalate exposure alters glucose metabolism and increases the risk of insulin resistance and DM. ${ }^{103}$

- Applications of a broad-spectrum sunscreen to the face and other sun-exposed areas (ie, neck and arms) should limit any enhancement of skin glycation related to sun exposure.

- The covering of pigmented lesions is likely to improve well-being.

These recommendations are intended to prevent and/or optimize the therapeutic management of DM-associated dermatoses, which become more prevalent with aging. ${ }^{104}$ Hence, they will improve the quality of life of DM patients, allowing them to better enjoy their lives.

\section{Acknowledgments}

The authors appreciate the excellent secretarial assistance of Mrs Ida Leclercq and Marie Pugliese.

\section{Disclosure}

This work was supported by a grant from the La Roche-Posay Pharmaceutical Laboratories. S Seité is an employee of $\mathrm{La}$ Roche-Posay Pharmaceutical Laboratories, Asnières, France. The authors report no other conflicts of interest.

\section{References}

1. Jelinek JE. The skin in diabetes. Diabetic Med. 1993;10(3):201-213.

2. Perez MI, Kohn SR. Cutaneous manifestations of diabetes mellitus. JAm Acad Dermatol. 1994;30(4):519-531.

3. Piérard-Franchimont C, Piérard GE, Lefèbvre P. Cutaneous manifestations of diabetes. Rev Med Liège. 1996;51(5):348-354. French.

4. Romano G, Moretti G, Di Benedetto A, et al. Skin lesions in diabetes mellitus: prevalence and clinical correlations. Diabetes Res Clin Pract. 1998;39(2):101-106.

5. Yosipovitch G, Hodak E, Vardi P, et al. The prevalence of cutaneous manifestations in IDDM patients and their association with diabetes risk factors and microvascular complications. Diabetes Care. 1998;21(4):506-509.
6. Flagothier C, Quatresooz P, Bourguignon R, Piérard-Franchimont C, Piérard GE. Cutaneous stigmata of diabetes mellitus. Rev Med Liège. 2005;60(5-6):553-559. French.

7. Kalus AA, Chien AJ, Olerud JE. Diabetes mellitus and other endocrine diseases. In: Goldsmith L, Katz S, Gilchrest B, Paller A, Leffell D, Wolff K, editors. Fitzpatrick's Dermatology in General Medicine, 8th ed. New York, NY: McGraw-Hill; 2012:151.

8. Diris N, Colomb M, Leymarie F, Durlach V, Caron J, Bernard P. Non infectious skin conditions associated with diabetes mellitus: a prospective study of 308 cases. Ann Dermatol Venereol. 2003; 130(11):1009-1014. French.

9. Nazratun N, Mahmood AA, Kuppusamy UR, Ahmad TS, Tan SY Diabetes mellitus exacerbates advanced glycation end product accumulation in the veins of end-stage renal failure patients. Vasc Med. 2006;11(4):245-250.

10. Jack M, Wright D. Role of advanced glycation end products and glyoxalase I in diabetic peripheral sensory neuropathy. Transl Res. 2012;159(5):355-365.

11. Kang P, Tian C, Jia C. Association of RAGE gene polymorphisms with type 2 diabetes mellitus, diabetic retinopathy and diabetic nephropathy. Gene. 2012;500(1):1-9.

12. Noordzij MJ, Mulder DJ, Oomen PH, et al. Skin autofluorescence and risk of micro- and macrovascular complications in patients with Type 2 diabetes mellitus-a multi-centre study. Diabet Med. 2012;29(12): $1556-1561$.

13. Perkins BA, Rabbani N, Weston A, et al. Serum levels of advanced glycation endproducts and other markers of protein damage in early diabetic nephropathy in type 1 diabetes. PLoS One. 2012;7(4):e35655.

14. Ramasamy R, Schmidt AM. Receptor for advanced glycation end products (RAGE) and implications for the pathophysiology of heart failure. Curr Heart Fail Rep. 2012;9(2):107-116.

15. Quatresooz P, Piérard GE. Immunohistochemical clues at aging of the skin microvascular unit. J Cutan Pathol. 2009;36(1):39-43.

16. Rendell M, Bamisedun O. Diabetic cutaneous microangiopathy. Am J Med. 1992;93(6):611-618.

17. Kolbe M, Kaufman JL, Friedman J, Dinerstein C, Mackenzie JW, Boyd CD. Changes in steady-state levels of mRNAs coding for type IV collagen, laminin and fibronectin following capillary basement membrane thickening in human adult onset diabetes. Connect Tissue Res. 1990;25(1):77-85.

18. Greives MR, Samra F, Pavlides SC, et al. Exogenous calreticulin improves diabetic wound healing. Wound Repair Regen. 2012;20(5): 715-730.

19. Pelizzo M, Zattra E, Nicolosi P, Peserico A, Garoli D, Alaibac M. In vitro evaluation of sunscreens: an update for the clinicians. ISRN Dermatol. 2012;2012:352135.

20. L'Alloret F, Candau D, Seité S, et al. New combination of ultraviolet absorbers in an oily emollient increases sunscreen efficacy and photostability. Dermatol Ther. 2012;2(1):4.

21. Uccioli L, Monticone G, Russo F, et al. Autonomic neuropathy and transcutaneous oxymetry in diabetic lower extremities. Diabetologia. 1994;37(10): 1051-1055.

22. Gerrits EG, Lutgers HL, Kleefstra N, et al. Skin autofluorescence: a tool to identify type 2 diabetic patients at risk for developing microvascular complications. Diabetes Care. 2008;31(3):517-521.

23. Sell DR, Nelson JF, Monnier VM. Effect of chronic aminoguanidine treatment on age-related glycation, glycoxidation, and collagen crosslinking in the Fischer 344 rat. J Gerontol A Biol Sci Med Sci. 2001;56(9): B405-B411

24. Pageon H, Técher MP, Asselineau D. Reconstructed skin modified by glycation of the dermal equivalent as a model for skin aging and its potential use to evaluate anti-glycation molecules. Exp Gerontol. 2008;43(6):584-588.

25. Draelos ZD, Yatskayer M, Raab S, Oresajo C. An evaluation of the effect of a topical product containing $\mathrm{C}$-xyloside and blueberry extract on the appearance of type II diabetic skin. J Cosmet Dermatol. 2009;8(2): $147-151$. 
26. Shemer A, Bergman R, Linn S, Kantor Y, Friedman-Birnbaum R. Diabetic dermopathy and internal complications in diabetes mellitus. Int J Dermatol. 1998;37(2):113-115.

27. Piérard GE,Arrese Estrada J, Piérard-Franchimont C, Deleixhe-Mauhin F. Is there a link between dendrocytes, fibrosis and sclerosis? Dermatologica. 1990;181(4):264-265.

28. Davison JE, Davies A, Moss C, Kirk JM, Taibjee SM, Agwu JC. Links between granuloma annulare, necrobiosis lipoidica diabeticorum and childhood diabetes: a matter of time? Pediatr Dermatol. 2010;27(2): 178-181.

29. Yosipovitch G, Loh KC, Hock OB. Medical pearl: Scleroderma-like skin changes in patients with diabetes mellitus. J Am Acad Dermatol. 2003;49(1):109-111.

30. Nikkels-Tassoudji N, Henry F, Letawe C, Piérard-Franchimont C, Lefebvre P, Piérard GE. Mechanical properties of the diabetic waxy skin. Dermatology. 1996;192(1):19-22.

31. Piérard-Franchmont C, Nikkels-Tassoudji N, Lefèbvre P, Piérard GE. Subclinical skin stiffening in adults suffering from type 1 diabetes mellitus. A comparison with Raynaud's syndrome. J Med Eng Technol. 1998;22(5):206-210.

32. Otto-Buczkowska E, Jarosz-Chobot P. Limited joint mobility syndrome in patients with diabetes. Int J Clin Pract. 2012;66(4):332-333.

33. Martin C, Requena L, Manrique K, Manzarbeltia FD, Rovira A. Scleredema diabeticorum in a patient with type 2 diabetes mellitus. Case Report Endocrinol. 2011;2011:560273.

34. Kroft EB, de Jong EM. Scleredema diabeticorum case series: successful treatment with UV-A1. Arch Dermatol. 2008;144(7):947-948.

35. Barde C, Masouyé I, Saurat JH, Le Gal FA. Scleroedema adultorum Buschke in a diabetic subject: intravenous immunoglobulin therapy. Ann Dermatol Venereol. 2009;136(4):360-363. French.

36. Lee FY, Chiu HY, Chiu HC. Treatment of acquired reactive perforating collagenosis with allopurinol incidentally improves scleredema diabeticorum. J Am Acad Dermatol. 2011;65(4):e115-e117.

37. Sehgal VN, Srivastava G, Aggarwal AK, Gupta M, Bhattacharya SN, Verma P. Noninsulin-dependent, type II diabetes mellitus-related dermatoses: part II. Skinmed. 2011;9(5):302-308.

38. ElMakki Ahmed M, Tamimi AO, Mahadi SI, Widatalla AH, Shawer MA. Hallux ulceration in diabetic patients. J Foot Ankle Surg. 2010;49(1):2-7.

39. Uhoda E, Debatisse B, Paquet P, Piérard-Franchimont C, Piérard GE. The so-called dry skin of the diabetic patient. Rev Med Liège. 2005; 60(5-6):560-563. French.

40. Piérard GE. What do you mean by dry skin? Dermatologica. 1989; 179(1):1-2.

41. Piérard GE, Goffin V, Hermanns-Lê T, Piérard-Franchimont C. Corneocyte desquamation. Int J Mol Med. 2000;6(2):217-221.

42. Sakai S, Kikuchi K, Satoh J, Tagami H, Inoue S. Functional properties of the stratum corneum in patients with diabetes mellitus: similarities to senile xerosis. Br J Dermatol. 2005;153(2):319-323.

43. Park HY, Kim JH, Jung M, et al. A long-standing hyperglycaemic condition impairs skin barrier by accelerating skin ageing process. Exp Dermatol. 2011;20(12):969-974.

44. Serup J. EEMCO guidance for the assessment of dry skin (xerosis) and ichthyosis: clinical scoring systems. Skin Res Technol. 1995;1(3): 109-114.

45. Piérard-Franchimont C, Petit L, Piérard GE. Skin surface patterns of xerotic legs: the flexural and accretive types. Int J Cosmet Sci. 2001; 23(2):121-126.

46. Piérard-Franchimong C, Quatresooz P, Piérard GE. Specular light reflectance of flakes in seborrhoeic dermatitis of the scalp: a pilot study. Clin Exp Dermatol. 2011;36(7):793-796.

47. Seirafi H, Farsinejad K, Firooz A, et al. Biophysical characteristics of skin in diabetes: a controlled study. J Eur Acad Dermatol Venereol. 2009;23(2):146-149.

48. Piérard-Franchimont C, Piérard GE. Beyond a glimpse at seasonal dry skin: a review. Exog Dermatol. 2002;1(1):3-6.
49. Mac-Mary S, Sainthillier JM, Humbert P. Dry skin and the environment. Exog Dermatol. 2004;3(1):72-80.

50. Piérard GE, Piérard-Franchimont C, Scheen A. Critical assessment of diabetic xerosis. Expert Opin Med Diag. 2013;7(2):201-207.

51. Pirot F, Morel B, Peyrot G, et al. Effects of osmosis on water-holding capacity of stratum corneum and skin hydration. Exog Dermatol. 2003;2(1):252-257.

52. Pirot F, Falson F, Pailler-Mattéi C, Maibach HI. Stratum corneum: an ideal osmometer? Exog Dermatol. 2004;3(6):339-349.

53. Berardesca E; European Expert Group for Efficacy Measurements on Cosmetics and Other Topical Products (EEMCO). EEMCO guidance for the assessment of stratum corneum hydration: electric methods. Skin Res Technol. 1997;3(2):126-132.

54. Fischer TW, Wigger-Alberti W, Elsner P. Assessment of "dry skin": current bioengineering methods and test designs. Skin Pharmacol Appl Skin Physiol. 2001;14(4):183-195.

55. Lee CM, Maibach HI. Bioengineering analysis of water hydration: an overview. Exog Dermatol. 2002;1(1):269-275.

56. O'goshi K, Serup J. Inter-instrumental variation of skin capacitance measured with the Corneometer. Skin Res Technol. 2005;11(2):107-109.

57. Lévêque JL, Xhauflaire-Uhoda E, Piéard GE. Skin capacitance imaging, a new technique for investigating skin surface properties. Eur $J$ Dermatol. 2006;16(5):500-506.

58. Xhauflaire-Uhoda E, Piérard GE, Quatresooz P. The skin landscape following nonoptical capacitance imaging. Am J Clin Dermatol. 2010;11(2):89-94.

59. Piérard-Franchimont C, Piérard GE. Skin surface stripping in diagnosing and monitoring inflammatory, xerotic, and neoplastic diseases. Pediatr Dermatol. 1985;2(3):180-184.

60. Piérard-Franchimont C, Piérard GE. Assessment of aging and actinic damages by cyanoacrylate skin surface strippings. Am J Dermatopathol. 1987;9(6):500-509.

61. Piérard GE, Piérard-Franchimont C, Saint-Léger D, Kligman AM. Squamometry: the assessment of xerosis by colorimetry of D-squame adhesive discs. J Soc Cosmet Chem. 1992;47:297-305.

62. Piérard GE. EEMCO guidance for the assessment of dry skin (xerosis) and ichthyosis: evaluation by stratum corneum strippings. Skin Res Technol. 1996;2(1):3-11.

63. Piérard-Franchimont C, Henry F, Piérard GE. The SACD method and the XLRS squamometry tests revisited. Int J Cosmet Sci. 2000;22(6): $437-446$.

64. Yoon HS, Baik SH, Oh CH. Quantitative measurement of desquamation and skin elasticity in diabetic patients. Skin Res Technol. 2002;8(4): 250-254.

65. Schatz H, Altmeyer PJ, Kligman A. Dry skin and scaling evaluated by D-squames and image analysis. In: Serup J, Jemec GBE, Grove GL, editors. Handbook of Non-Invasive Methods and the Skin, 2nd ed. Boca Raton, FA: CRC Press; 2006:375-379.

66. Takahashi M, Black D, Hughes B, Marks R. Exploration of a quantitative dansyl chloride technique for measurement of the rate of desquamation. Clin Exp Dermatol. 1987;12(4):246-249.

67. Piérard GE. Microscopic evaluation of dansyl chloride test. Dermatology. 1992;185(1):37-40.

68. Paye M, Simion FA, Piérard GE. Dansyl chloride labelling of stratum corneum: its rapid extraction from skin predict skin irritation due to surfactants and cleansing products. Contact Dermatitis. 1994;30(2): 91-96.

69. Piérard GE, Piérard-Franchimont C. Dihydroxyacetone test as a substitute for the dansyl chloride test. Dermatology. 1993;186(2): 133-137.

70. Uhoda E, Piérard-Franchimont C, Debatisse B, Wang X, Piérard GE. Repair kinetics of stratum corneum under repeated insults. Exog Dermatol. 2004;3(1):7-11.

71. Pavicic T, Korting HC. Xerosis and callus formation as a key to the diabetic foot syndrome: dermatologic view of the problem and its management. J Dtsch Dermatol Ges. 2006;4(11):935-941. 
72. Pham HT, Exelbert L, Segal-Owens A, Veves A. A prospective, randomized, controlled double-blind study of a moisturizer for xerosis of the feet in patients with diabetes. Ostomy Wound Manage. 2002;48(5): 30-36.

73. Lodén M. Role of topical emollients and moisturizers in the treatment of dry skin barrier disorders. Am J Clin Dermatol. 2003;4(11):771-788.

74. Lodén M. The clinical benefit of moisturizers. J Eur Acad Dermatol Venereol. 2005;19(6):672-688.

75. Xhauflaire-Uhoda E, Fontaine K, Piérard GE. Kinetics of moisturizing and firming effects of cosmetic formulations. Int J Cosmet Sci. 2008;30(2):131-138.

76. Ananthapadmanabhan KP, Yang L, Vincent C, et al. A novel technology in mild and moisturizing cleansing liquids. Cosmet Dermatol. 2009; 22(6):307-316.

77. Quatresooz P, Piérard-Franchimont C, Szepetiuk G, Devillers C, Piérard GE. Fungal chitin-glucan scaffold for managing diabetic xerosis of the feet in menopausal women. Expert Opin Pharmacother. 2009;10(14):2221-2229.

78. Shi VY, Tran K, Lio PA. A comparison of physicochemical properties of a selection of modern moisturizers: hydrophilic index and $\mathrm{pH}$. J Drugs Dermatol. 2012;11(5):633-636.

79. Seité S, Khemis A, Rougier A, Ortonne JP. Importance of treatment of skin xerosis in diabetes. J Eur Acad Dermatol Venereol. 2011;25(5): 607-609.

80. Hermanns-Lê T, Hermanns JF, Piérard GE. Juvenile acanthosis nigricans and insulin resistance. Pediatr Dermatol. 2002;19(1):12-14.

81. Hermanns-Lê T, Scheen A, Piérard GE. Acanthosis nigricans associated with insulin resistance; pathophysiology and management. Am J Clin Dermatol. 2004;5(3):199-203.

82. Romo A, Benavides S. Treatment options in insulin resistance obesity-related acanthosis nigricans. Ann Pharmacother. 2008;42(7): 1090-1094.

83. Piérard-Franchimont C, Jebali A, Ezzine N, Letawe C, Piérard GE. Seasonal variations in polymorphis nail surface changes associated with diabetes mellitus. J Eur Acad Dermatol Venereol. 1996;7(2):182-196.

84. Piérard GE, Piérard-Franchimont $C$. The nail under fungal siege in patients with type II diabetes mellitus. Mycoses. 2005;48(5):339-342.

85. Piérard GE, Piérard-Franchimont C, Marks R, Elsner P; EEMCO Group (European Expert Group on Efficacy Measurement of Cosmetics and Other Topical Products). EEMCO guidance for the assessment of hair shedding and alopecia. Skin Pharmacol Physiol. 2004;17(2):98-110.

86. Goodman JI. Diabetic anhidrosis. Am J Med. 1966;41(5):831-835.

87. Kennedy WR, Sakuta M, Sutherland D, Goetz FC. Quantification of the sweating deficit in diabetes mellitus. Ann Neurol. 1984;15(5): $482-488$

88. Fealey RD, Low PA, Thomas JE. Thermoregulatory sweating abnormalities in diabetes mellitus. Mayo Clinic Proc. 1989;64(6):617-628.
89. Piérard GE, Elsner P, Marks R, Masson P, Paye M; EEMCO group. EEMCO guidance for the efficacy assessment of antiperspirants and deodorants. Skin Pharmacol Appl Skin Physiol. 2003;16(5): 324-342.

90. Vinik AI, Maser RE, Mitchell BD, Freeman R. Diabetic autonomic neuropathy. Diabetes Care. 2003;26(5):1553-1579.

91. Petrofsky JS, Lee S, Patterson C, Cole M, Stewart B. Sweat production during global heating and during isometric exercise in people with diabetes. Med Sci Monit. 2005;11(11):CR515-CR521.

92. Philips JC, Marchand M, Scheen AJ. Pulse pressure and cardiovascular autonomic neuropathy according to duration of type 1 diabetes. Diabetes Metab Res Rev. 2009;25(5):442-451.

93. Provitera V, Nolano M, Caporaso G, Stancanelli A, Santoro L, Kennedy WR. Evaluation of sudomotor function in diabetes using the dynamic sweat test. Neurology. 2010;74(1):50-56.

94. Xhauflaire-Uhoda E, Mayeux G, Quatresooz P, Scheen A, Piérard GE Facing up to the imperceptible perspiration. Modulation influences by diabetic neuropathy, physical exercise and antiperspirant. Skin Res Technol. 2011;17(4):487-493.

95. Noël F, Piérard-Franchimont C, Piérard GE, Quatresooz P. Sweaty skin, background and assessments. Int J Dermatol. 2012;51(6):647-655.

96. Caucanas M, Piérard-Franchimont C, Piérard GE. Pruritus, a frequent worry. Rev Med Liège. 2010;65(10):593-597. French.

97. Rurangirwa A, Piérard-Franchimont C, Piérard GE. Growth of Candida albicans on the stratum corneum of diabetic and non-diabetic patients. Mycoses. 1990;33(5):253-255.

98. Quatresooz P, Paquet P, Hermanns-Lê T, Piérard GE. Molecular mapping of Factor XIIIa-enriched dendrocytes in the skin (Review) Int J Mol Med. 2008;22(4):403-409.

99. Kumar KV, Priya S, Shaikh A, Prusty P. Diabetes in young - unusual case presentation. J Pediatr Endocrinol Metab. 2011;24(7-8):581-583.

100. Nakatani K, Kurose T, Hyo T, et al. Drug-induced generalized skin eruption in a diabetes mellitus patient receiving a dipeptidyl peptidase-4 inhibitor plus metformin. Diabetes Ther. 2012;3(1):14.

101. Piérard-Franchimont C, Hermanns-Lê T, Scheen AJ, Piérard GE. Cutaneous complications of insulin therapy. A drug-induced condition on the decline. Rev Med Liège. 2005;60(5-6):564-565. French.

102. Radermecker RP, Piérard GE, Scheen AJ. Lipodystrophy reactions to insulin: effects of continuous insulin infusion and new insulin analogs. Am J Clin Dermatol. 2007;8(1):21-28.

103. Lind PM, Zethelius B, Lind L. Circulating levels of phthalate metabolites are associated with prevalent diabetes in the elderly. Diabetes Care. 2012;35(7):1519-1524.

104. Drab SR. Recognizing the rising impact of diabetes in seniors and implications for its management. Consult Pharm. 2009;24 Suppl B: S5-S10.
Clinical, Cosmetic and Investigational Dermatology

\section{Publish your work in this journal}

Clinical, Cosmetic and Investigational Dermatology is an international, peer-reviewed, open access, online journal that focuses on the latest clinical and experimental research in all aspects of skin disease and cosmetic interventions. All areas of dermatology will be covered; contributions will be welcomed from all clinicians and

\section{Dovepress}

basic science researchers globally. This journal is indexed on CAS. The manuscript management system is completely online and includes a very quick and fair peer-review system, which is all easy to use. Visit http://www.dovepress.com/testimonials.php to read real quotes from published authors. 